\title{
The ORIgins, Early History and EVolution OF THE ENGLISH CRIMINAL TRIAL JURY
}

\section{SANJEEV ANAND}

This article presents an historical account of the English criminal trial jury from its birsh in the thirteenth century. as a largely self-informing instifution that replaced the ordeals, to the nineteenth century, where the passivity of the modern irial jury became firmly established as a result of the influence of legal counsel and the development of the adversarial criminal trial. The expansive timeline that is assessed reveals that public distrust of the motsves and competency of jurors is a recurrent theme and not simply a modern phenomenon. However. the historical evidence suggests that criminal trial jurors tended not to suffer from the deficiencies attributed to them by some commentators. Because the jury has undergone significant transformations in the past and survived, modern day proponents of the criminal trial jury could argue that it is capable of continuing to accommodate significant changes to the practices that govern its conduct. For those inclined towards the reform of the English criminal trial jury, some of the features noted by the author that have been discarded over time may be considered deserving of revival.
Cel arsicle raconte l'histoire du jury des procès criminels anglais a partir de sa naissance au XIIr siècle, essentiellement en tont qu'instifution autoinformante venue remplacer les supplices, jusqu iau $X I X^{*}$ slècle lorsque la passivité des jury de procès moderness 'est fermement installée suise à l' influence des conseillers juridiques et du developpement du procès criminel adversatif. Vul'importante période de remps traitée, il est clair que la méfiance du public à l'égard du mobile el des compétences des jurès revient souvent ef qu'il ne s'agit pas là d'un phénomène moderne. Cependant, le témoignage de Thistoire laisse penser que les jures de procès criminels ne semblaient pas souffrir des deficiences que certains commentateurs leur attribuaient. Comme le jury a fait l'objet de transformations considérables et qu'il a survicu, ceux qui aujourd' hui sont en faveur du jury pour les procès criminels pourraient faire valoir qu'il peut continuer à apporter d'importants changements aux pratiques qui régissent sa conduite. Pour ceux qui sont portés vers la réforme du jury du process criminel anglais. cerlaines des caractéristigues notées par l'auteur et abandonnies au fil du temps pourraient réapparaitre.

\section{TABLE OF CONTENTS}

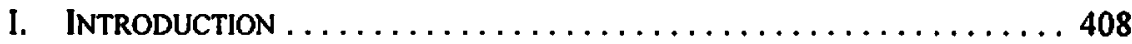

II. THE PRE-Criminal TRIal JURY Forms of ProOF

AND THE EMERGENCE OF THE CRIMINAL TRIAL JURY . . . . . . . . . . 409

A. COMPURGation OR WAgER OF LAW ................ 409

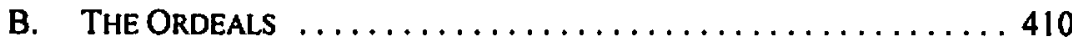

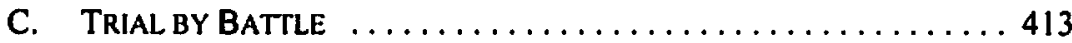

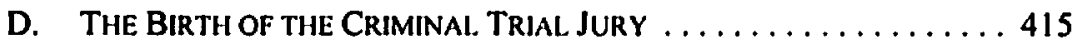

III. The Changing Nature of the Criminal. Trial Jury

IN ENGLAND FROM THE 1200 S TO THE 1800 S ............ 417

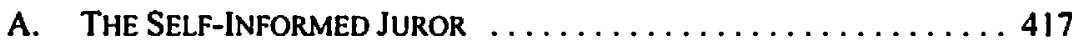

B. The Rise of the Witness Trial $\ldots \ldots \ldots \ldots \ldots \ldots \ldots \ldots .418$

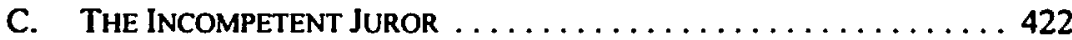

D. THE CORRUPt JUROR $\ldots \ldots \ldots \ldots \ldots \ldots \ldots \ldots \ldots \ldots \ldots \ldots \ldots$

Associate Professor, Faculty of Law. University of Alberta. The author thanks his research assistants, Jessica Buckwold and Heather Manweiller, for their tireless efforts. The author also expresses gratitude to Professors John Law and Philip Girard for their many helpful research suggestions. Nicholette $\wedge$ nand and Laurel Lui for their invaluable editing assistance and Priya and Seraphina Anand for their patience during the writing process. 


\section{E. SYSTEMIC EXIGENCIES AND THEIR INFLUENCE}

ON JURY PRACTICE . . . . . . . . . . . . . . . . . . . . 425

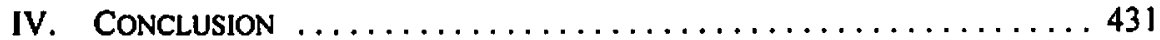

\section{INTRODUCTION}

Although the first true criminal trial juries in England can be traced to the first quarter of the thirteenth century, the trial juries of that time period bear little resemblance to the juries of today. Indeed the typical modern criminal trial jury, consisting of 12 people who do not know one another or any of the participants in the trial, who have never sat on a jury before, who are instructed not to seek out any information about the case but simply to assess the evidence presented to them, and who are asked to render only a general unanimous verdict of guilty or not guilty ${ }^{1}$ but not to disclose reasons for the verdict, is a relatively recent phenomenon.

In this article, I examine the history of the criminal trial jury in England prior to its inception in the thirteenth century until the establishment of the adversarial criminal trial in the nineteenth century. In the course of this examination, a number of gaps that exist in the scholarship on the origins and evolution of the English criminal trial jury are filled. For example, descriptions of the pre-criminal trial jury forms of proof abound in the historical literature; however, the nexus between the demise of these forms of proof and the rise of the criminal trial jury, albeit alluded to by various historians, has seldom been described in detail. Moreover, despite the fact that the history of the English criminal trial jury has been the subject of a great deal of scholarly inquiry, legal historians have tended to focus on the characteristics of the criminal trial jury during discrete time spans of short duration. As a result, important long-term trends in the metamorphoses of the jury have gone largely unnoticed. The relatively short time periods examined in much of the historical work on the English criminal trial jury have impeded assessments of the accuracy of certain popular historical depictions of typical jurors.

There also exists a less lofty and yet extremely important reason for my writing this history of the English criminal trial jury. The terminology and methodology employed by many historians are foreign to many non-historians, including lawyers and legal academics. Thus, there is a need for an historical account of the English criminal trial jury that is broadly accessible.

My exploration of the history of the English criminal trial jury reveals that it has not been a static, inflexible institution but one that has undergone significant and profound reforms over hundreds of years. Nevertheless, the one theme that prevails throughout this history is the growing passivity of the criminal trial jury.

In 1967, the Parliament of the Uniled Kingdom recognized the validity of "majority" verdicts in certain circumstances. Initially jurors are instructed to reach a unanimous verdict. If after two hours of deliberations such a verdict has not been rendered, the trial judge can accept, in a case involving at least 11 jurors, a verdict agreed upon by ten of them. In cases involving ten jurors, nine of them must agree on the verdict. See Criminal Justice Act 1967 (U.K.), 1967, c. 80, s. 13. The provision that governs majority verdicts in criminal trials today is Juries $A c t 1974$ (U.K.), 1974. c. 23, s. 17. 
This article is divided into two parts. In the first part, I describe the pre-criminal trial jury forms of proof that existed in England, their relationship to various types of criminal juries, and how the demise of one pre-criminal trial jury form of proof led to the establishment of the first real criminal trial juries. In the second part, I focus on the changing nature of the criminal trial jury in England from the 1200 s to the 1800 s. During the course of this exploration, I assess the accuracy of certain historical depictions of the typical criminal trial juror, including the self-informed juror, the incompetent juror and the corrupt juror.

\section{The Pre-Criminal Trial Jury forms of Proof AND THE EMERGENCE OF THE CRIMINAL. TRIAL. JURY}

The English developed three forms of proof that predate the use of the criminal trial jury. These forms of proof were compurgation or wager of law, the ordeal and combat. Each type of proof was linked to a specific form of prosecution and type of criminal jury.

\section{A. COMPURGation OR Wager OF LAW}

Compurgation required two things of the accused. First, the accused had to swear an oath that he did not commit the offence charged. Second, he was required to produce a certain number of oath-helpers or compurgators to back his denial by their oaths. If both these requirements were satisfied, the accused was absolved of criminal liability. The rationale underpinning proof by wager of law was that individuals would be loath to endanger their immortal souls and/or risk earthly punishment for perjury by swearing falsely. If the compurgators should vary in any manner from the formal oath required, the oath "burst" and the accused was found guilty of the offence.

Not every accused could resort to wager of law. Obviously compurgation was of no avail to an accused who could not gather up the requisite number of oath-helpers. But the oaths of some accused were also considered untrustworthy. For example, foreigners were precluded from clearing themselves by way of wager of law, as were those individuals who had previously been suspected of criminal acts. ${ }^{2}$ Unfree accused could also not purge themselves by way of compurgation unless they were vouched for by their Lords. ${ }^{3}$ The more serious the offence, the less likely it would be for an accused to be allowed proof through compurgation. ${ }^{4}$ Moreover, those who had been caught red-handed or had confessed could not avail themselves of any proof at all; such individuals were subject to immediate punishment."

Compurgation was only available if the accused was the recipient of an adverse judgment of one type of criminal jury - the jury of presentment. This jury, which was to eventually evolve into the grand jury, was composed of representatives of the county. These representatives were called upon to report to the justices anyone who was accused of, or reputed to have committed, certain serious offences. An individual presented upon repute

Roben Bartlett, Trial By Fire And Water (Oxford: Clarendon Press, 1986) at $31-32$

lbid. at 32-33.

Leonard W. Levy, The Palladium of Justice (Chicago: Ivan R. Dee, 1999) at 5.

Thomas Andrew Green, Verdict According 10 Conscience (Chicago: University of Chicago Press. 1985)

at 8 [Green, Verdict]. 
alone made proof by compurgation while one presented upon specific information made proof by ordeal. ${ }^{6}$

Albeit that wager of law was not an uncommon method of dealing with criminal accusations in the tenth and eleventh centuries, by the early twelfth century compurgation had disappeared from the criminal process, at least for serious offences. ${ }^{7}$ The reason for the decline of wager of law was that the form of oath taken by the compurgators had changed. Originally, the compurgators took the same oath as their principal. In other words, the oathhelpers as well as the accused swore that the accused was not guilty of the crime alleged. Consequently, the compurgators were liable to the same penalties for perjury as their principal. But in the twelfth century the oath was altered because the papacy thought that it provided too much of a temptation to oath-helpers to commit perjury. As a result, the compurgators had only to swear that they believed that the accused was telling the truth. While the new oath removed the temptation to compurgators to commit perjury, it also destroyed the efficacy of this method of proof because it prevented any effective earthly punishment to a compurgator who swore falsely. ${ }^{8}$ The official end of compurgation as a proof in serious criminal matters came with the passing of the Assize of Clarendon, an ordinance enacted in 1166 by Henry II, by which the monarch proclaimed that all those prosecuted by indictment (those individuals who received an adverse verdict from the jury of presentment) should make their proof by the ordeal of cold water. ${ }^{9}$

\section{B. The Ordeals}

There were a number of different types of ordeals used in England, but by far the most common ones were the ordeals of cold water and of hot iron. In the ordeal of cold water, the accused was lowered into a pond or other body of water that had received a blessing by clergy. If the presiding priest concluded that the accused sank when placed in the water, the accused was adjudged innocent and hopefully retrieved before drowning. If the accused appeared to float, he was judged guilty of the offence charged. ${ }^{10}$ In the ordeal of hot iron, a piece of iron was heated in a fire and blessed; then, while the iron was still hot, it was given to the accused and required to be held by him while he walked a number of paces. The hand was then bound and inspected by a member of the clergy a few days later. If on the day of inspection the hand appeared to be infected, God was taken to have decided against the accused."

The ordeal, like compurgation, was inscrutable. The verdict of the ordeal was formalistically accepted without discussion, and no reasons accompanied the verdict.

Naomi D. Ilurnard, "The Jury of Presentment and the Assize of Clarendon" (1941) 56 English Historical Review 374 at 391.92.

Bartlett, supra note 2 at 64.

Sir William Holdsworth. A History of English l.aw: Volume 1, 7th ed. (London: Sweet \& Maxwell. 1969) at 305-306 (original text published London: Methuen, 1903).

Margaret H. Kerr, Richard D. Forsyth \& Michael J. Plyley, "Cold Water and Hot Iron: Trial by Ordeal in England" (1992) 22 Journal of Interdisciplinary History 573 at 573: Green. Verdict, supra note 5 at 7.

1") Kerr, Forsyth \& Plyley, ibid. at 582-83.

Ibid. at 588-89. 
Those individuals who received unfavorable verdicts from the jury of presentment were adjudged by the ordeal as a final proof in a variety of circumstances. Prior to the Assize of Clarendon, if the accused was a foreigner, had been suspected of criminal offences before, was unfree, was accused of a particularly serious offence or was presented based on specific information, he was forced to undergo the ordeal rather than compurgation.

It is easy to subscribe to the notion that the ordeal was abandoned because it was the product of a superstitious age and that it simply vanished in more rational times, but such an account of the demise of the ordeal would be mistaken. The ordeal was abandoned as a proof in criminal matters in England when the Fourth Lateran Council convened by Pope Innocent III in 1215 prohibited the clergy from participating in judicial proofs by ordeal. Without priests to read the signs of God and administer the appropriate blessings, the ordeal could not be utilized. The Fourth Lateran Council did not outlaw the ordeal because in the thirteenth century the majority of clergy, nobility or common folk believed that God did not intervene to change the physical properties of the world nor did the ban respond to a declining belief in immanent justice. A literal belief in the transmutation of Christ's body was accepted Church doctrine in the form of the Eucharist. Moreover, the causes of natural disasters or outbreaks of plague were still being attributed to the sins of those victimized or afflicted.'

The Church terminated clerical involvement in the ordeals for two reasons. The first reason was that, through the twelfth and into the thirteenth centuries, written authorities assumed an increasingly important position in the Church. In regard to the ordeal, scholars brought attention to the fact that the Roman law was silent, the older canonical law was ambivalent and scriptural support in the form of the Bible was scant. ${ }^{13}$ So the ordeal was vulnerable because it lacked good written authority. The second rationale for the Church's pronouncement of 1215 was that the ordeal tempted God. Bartlett explains this idea as follows:

Confidence in the ordeal rested upon the conviction that its results were guaranteed to manifest God's judgement. Growing doubts about the ordeal in the twelfth century were not primarily due to an increasing uncertainty about the fact of such manifestations of God's judgement. Rather it was the guaranteed nature of the result which was in question. It was increasingly viewed as impious to believe that a constructed human test - the ordeal — could "force" God to show his hand. That was testing God. ${ }^{14}$

It is a common modern belief that the ordeal was an unfair form of proof, especially when one considers that, beginning in the twelfth century, monetary compensatory penalties for those found guilty of serious criminal offences (felonies) were being replaced by maiming and, increasingly, by capital punishment. Most people think that the operation of the laws of physics and the principles of buoyancy meant that the majority of individuals subjected to the ordeal of cold water floated and therefore they were judged guilty. In addition, in an age before antibiotic ointments it is reasonable to assume that a substantial proportion of those

1: See Paul R. Hyams, "Jrial by Ordeal: The Key to Proof in the Early Common Law" in Morris S. Arnold et al., eds., On the Laws and Customs of England (Chapel Hill: The University of North Carolina Press. 1981) 90 at 125: and Bartlett, stupra note 2 at 162-65.

"Trisha Olson, "Of Enchantment: The Passing of the Ordeals and the Rise of the Jury Trial" (2000) 50 Syracuse L. Rev. 109 at 168.

14 Bartlett, supra note 2 at 86. 
who underwent the ordeal of hot iron subsequently developed an infection and thus failed the ordeal. But a large number, perhaps even a majority, of those that underwent the ordeals were adjudged innocent.

There have been a number of offered explanations for this high acquittal rate. In relation to the ordeal of cold water, it has been observed that it was known in medieval times, perhaps commonly known, that a person's chances of sinking when placed in water increase if the

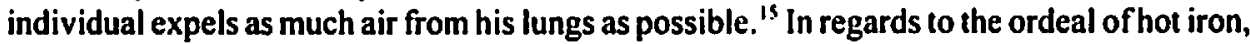
it has been postulated that, at least in some cases, those who administered the ordeal felt doubtful about the guilt of the accused and may have let the iron cool, or they interpreted a burned hand liberally. ${ }^{16}$ It has also been observed that infections from burn wounds do not usually appear before the fifth post-burn day. ${ }^{17}$ Thus, many of those who had infected burns would not appear to have an infection on judgment day. Finally, it appears that many individuals who did undergo the ordeal of hot iron would not have incurred infections because the incidence of serious infection varies with the size of the burn and such infections are generally uncommon where the burn covers less than 30 percent of the total body surface. $^{18}$

But for those people required to undergo the ordeal, and who were not fortunate enough to benefit from a lenient presiding priest, the proof itself could be conceived as a type of punishment, a punishment that was meted out before there was a finding of guilt. Such a scenario would certainly run afoul of modern conceptions of due process.

However, it has been asserted that there was a finding of guilt, of sorts, before the accused was subjected to the ordeal. Until relatively recently it was thought that the verdict of the jury of presentment was not really a verdict at all, but simply a report of accusation and/or suspicion. Indeed, presenting jurors who failed to report all accusations, such as those contained within coroners' reports or other official reports before the justices, were subject to being fined. Thus it is understandable that historians originally believed that the jury of presentment simply constituted a conduit for all private accusations and rumors of misdoing. Nevertheless, Roger D. Groot has shown that although most presenting jurors were vigilant about identifying all persons about whom there was suspicion, the jury of presentment then opined about the accuracy of the accusations. ${ }^{19}$ The accused faced the ordeal only when the presenting jury indicated that the accusation was accurate. Consequently the jury of presentment formulated a medial verdict of guilt before the accused was put to the final verdict of the ordeal. ${ }^{20}$

Kerr, Forsyth \& Plyley, supra note 9 at 587

J.H. Baker, An Introduction to English Legal Hisiory, 4 th ed. (L.ondon: Butterworths L.exisNexis, 2002) at 5 .

Kerr, Forsylh \& Plyley, supra note 9 at 593.

Ibid.

Roger D. Groot, "The Jury of Presentment Before 1215" (1982) 26 Am. J. I.egal Hist. I.

Actually, in some respects. an adverse verdict of the presenting jury was final because even if the accused went on to be cleared by the ordeal, the Assize of Clarendon required the individual to leave the country if he was of ill repute. This part of the Assize of Clarendon is often construed as evidence that Henry II distrusted the ordeal as a mode of proof. For a contrary interpretation, see Bartlett. supra note 2 at 67-69. 
The initiation of serious criminal proceedings could be commenced in medieval and even early modern times by a means other than the jury of presentment. An appeal of felony was a private form of prosecution initiated by the oral accusation of crime made by the victim, his or her kin if the victim was deceased, or by approvers. An approver was an accomplice who confessed his own part in the felony but whose life was spared in return for his undertaking to prosecute an agreed number of fellow criminals. The appeal of felony was the standard form of criminal prosecution until the twelfth century but for a variety of reasons, including the extreme technicality of the procedure and the judicial unwillingness to overlook minor deviations from the strict forms required, ${ }^{21}$ by the fourteenth century most prosecutions went by way of indictment.

\section{TRIAL By BattLe}

For able-bodied men, the standard mode of proof in relation to an appeal was trial by battle or judicial combat, a manner of proof that was imported to England by the Normans after the Conquest of 1066. However, those accused men who could not offer trial by battle because of a disability or because of age, and all accused women, were put to the ordeal of cold water or hot iron. In trial by battle, court officials attended a field at dawn and were joined by the two combatants, the accuser or appellor, and the accused or appellee. The appellor and appellee were dressed in suits of armour but were bare-headed, bare-legged from the knees downward, and bare-armed from the elbow down. The only weapons they had were batons, although some sources indicate that the batons had "crooks" made of homs that made the weapons similar to tomahawks, and four-cornered leather shields. ${ }^{22}$ Both combatants swore oaths: the appellor swore that the appellee had committed the crime, and the appellee swore that he was innocent of the wrongdoing. The battle then began, and the two fought until one of the combatants died or yielded by crying "craven" or until evening when the stars appeared. If the appellee could survive until the stars appeared, he was judged innocent. ${ }^{23}$

Trial by battle was similar to trial by ordeal in a number of ways. Both methods of proof were supposed to reveal the judgment of God and both yielded inscrutable verdicts. The Church looked disfavourably upon trial by ordeal and trial by battle, but because the latter type of proof did not require the active participation of clergy, the papacy's disapproval of it had little effect. ${ }^{24}$

Before an appellee was forced to undergo trial by battle, or if unable to wage combat, trial by ordeal, he could, upon request, obtain a medial verdict by a jury. Those appealed by approvers often sought an inquest de fidelitate, in which the jury was ostensibly asked to

21 For a thorough and interesting discussion of the other reasons for the decline of the appeal by the end of the thirteenth century, and an account that advances the argument that lack of judicial respect lor private settlements was the most important causal factor tor the decline of the appeal in this time period, see Daniel Kleman, "Setllement and the Decline of Private Prosecution in Thirteenth-Century I:ngland" (2001) 19 L.H.R. I.

2: See Henry Charles Lea, The Duel and the Oath (Philadelphia: University of Pennsylvania Press. 1974) at 176 (first published in 1866 as Parts I and II of Superstition and Force)

"Deborah A. Satanove, "Knights at Dawn: A History of the Trial Process" (2000) 58 Advocale (13.C, 63 at 65 .

:4 Bartlett, supra note 2 at 117-22. 
render a verdict about the repute of the accused. If the accused was deemed to be of ill repute, he underwent physical proof. However, if the accused was determined to be a lawful person, he was acquitted without having to undergo physical proof. Those appealed by alleged victims of felony or their kin could seek the writ de odio et atia. By buying such a writ, the appellee ostensibly asked the jury to decide if the appeal had been made from hate and spite. If the appeal was determined not to have been made from hate and spite, the accused underwent physical proof. If it was concluded that the appeal was prompted by hate and spite, the accused was acquitted without having to undergo physical proof. Groot has demonstrated that although the jury in appeals was seemingly directed to decide questions about the accused's character in the inquest de fidelitate, and about the accuser's motivations in the de odio et atia inquest, the principal issues in these inquests pertained to whether or not the appeals were meritorious. ${ }^{25}$ Consequently, the juries involved in private criminal prosecutions, like the jury of presentment, rendered a medial verdict of guilt before the accused was subjected to the final verdict of the applicable physical form of proof.

Although trial by battle was not formally abolished by statute as a mode of proof in criminal matters until $1819,{ }^{26}$ the last judicial duel arising from a criminal matter in England was fought in $1456 .{ }^{27}$ After the establishment of trial juries that rendered final verdicts in the thirteenth century, appellees had the option of choosing trial by jury instead of trial by battle, and most did so. Moreover, by the sixteenth century, judges limited the scope of trial by battle by creating a number of restrictions as to when it was available. ${ }^{28}$ It is clear that one of the principal concerns that prompted these judicial restrictions on trial by battle was the need to limit the ability of physically strong criminals to choose trial by battle against weaker victims of their crimes and thereby escape criminal liability. Clearly, by the sixteenth century many doubted that God was revealing himself through the verdict of trial by battle since the stronger party invariably prevailed in judicial combat.

The decision of the Fourth Lateran Council in 1215 to forbid clerical participation in the ordeal created uncertainty for the English criminal justice system. The ordeal could no longer be resorted to and, as a consequence, a method had to be found to try those who were prosecuted by indictment and those who were privately prosecuted but where either the appellee or the appellor was precluded from offering trial by battle. Some instructions were given to the justices in 1219. . $^{29}$ These instructions acknowledged that the ordeal had been abolished and that an appropriate judicial response had not yet been formulated. The instructions provided that those accused of major crimes about which there was strong suspicion of guilt should be committed to prison for safekeeping; that those accused of medium crimes, for which the ordeal would have been appropriate, should be permitted to be exiled from the realm; and that those accused of minor crimes about which there was no

See Roger D. Groot, "The Jury in Private Criminal Prosecutions Before 1215" (1983) 27 Am. J. Legal Hist. 113; and Roger D. Groot, "The Early-Thirteenth-Century Criminal Jury" in J.S. Cockburn \& Thomas A. Green, eds., Twelve Good Men and True (Princeton: Princeton University Press, 1988) 3 [Groot. "The Early-Thirteenth-Century Criminal Jury"]. Stat. 59 Geo Ill, c. 46. Actually, this statute eliminated the appeal as a method of prosecution, and hence it also terminated recourse to trial by battle in criminal cases. M.J. Russell. "Trial by Battle and the Appeals of Felony" (1980) I J. Legal Hist. 135 at 154. Daniel R. Emst. "The Moribund Appeal of Death: Compensating Survivors and Controlling Juries in Early Modern England" (1984) 28 Am. J. Legal Hist. I64 at 167; and Baker, supra note 16 at 504.

$\because \quad$ Groot. "The Early.Thirteenth-Century Criminal Jury," supra note 25 at 10. 
strong suspicion should be placed under good-conduct pledges. Other cases were specifically left to the discretion of the justices. ${ }^{30}$

\section{The Birth of the Criminal Trial Jury}

The abolition of the ordeal, and the lack of definitive directions to the justices in the order of 1219 , led to a period of great experimentation by the justices. In order to implement the directives of the order of 1219 , the justices began to order medial jury inquests for all appeals, even when they were not sought by appellees, so that it could be determined whether strong suspicion of guilt existed such that the accused should be kept in perpetual imprisonment pursuant to the directive of 1219. Probably because the justices knew that indefinite imprisonment would soon overload the few prisons in the country, the justices immediately began to deviate from the directive of 1219 . For example there is evidence that in York in 1219, in an appeal of rape, where the appellor was a woman and could not offer trial by battle and where the appellee could no longer be forced to undergo trial by ordeal, the court ordered an unsought de odio et atia inquest. After the jury found that the suit was reasonably made, the accused was ordered incarcerated until he paid a fine. "It is clear that the appellee was not treated as if he was fully guilty, because the sentence for rape was castration, but the medial jury verdict was the basis for a milder punitive sanction. In 1220 , the justices were faced with a situation in which an inquest de fidelitate was ordered against an accused who was appealed by an approver and the appellee failed the inquest. He should have been awarded combat as proof, but his approver had already been executed after appealing another man and losing the trial by combat. The result of the inquest de fidelitate meant that the accused was heavily suspected of a serious crime and, pursuant to the directive of 1219, he faced perpetual imprisonment. However, the justices gave him a choice: the accused could opt to accept a final jury verdict. Faced with the certainty of indefinite imprisonment or the chance for an acquittal via a final jury verdict, the accused chose the latter and the English criminal trial jury was borm. ${ }^{32}$ There is evidence that, between 1221 and 1222 , the final convicting criminal trial jury was extended from approvers' appeals to prosecutions by way of indictment and, finally, to other appeals of felony. ${ }^{33}$

The accused had to consent to trial by jury. Soon some accused began to refuse this mode of proof. Those who had suffered adverse medial verdicts and could not be subjected to trial by battle were, pursuant to the 1219 directive, put in jail. However, perhaps because the jails were nearing their capacity, justices began releasing heavily suspected individuals accused of serious crimes on condition that they leave the realm, and some of these accused were even permitted to stay in the Kingdom upon giving pledges to keep the peace. ${ }^{34}$

The justices considered this situation problematic and devised a solution. In late 1221 or early 1222 , accused who could not be subjected to trial by battle but refused trial by jury were forced to undergo trial by an altered form of jury. But to understand an altered jury, it is first important to understand that a normal criminal trial jury in 1221 to 1222 consisted of

Ibid.

lbid. at 12 .

lbid. at 17.21 .

Ibid. at 21-28.

Ibid. at 30. 
32 people: 12 "hundredors" and 20 villagers, five from each of the four "vills" closest to the offence. The so-called hundredors were people drawn from the medieval subdivision of a county known as a "hundred." Similarly, villagers were drawn from the subdivision of a hundred known as a "vill," which today would roughly correspond to a civil parish. But the altered criminal trial jury forced upon recalcitrant accused did not include villagers and was larger than a normal criminal trial jury. It consisted of 36 people: 12 hundredors and 24 knights. Because the likelihood of conviction increased with this altered jury, accused stopped refusing trial by jury, and the experiment of forcing trial by augmented jury ceased almost immediately. ${ }^{35}$ Indeed, shortly after 1222 , the normal criminal trial jury was itself reformed so that the 20 villagers were eliminated and only 12 hundredors remained. ${ }^{36}$

However, after a short period of compliance, accused again began to refuse trial by jury and opt for indefinite imprisonment pursuant to the directive of 1219 . For some reason, judges did not reinstitute the successful experiment of forcing trial by augmented jury on recalcitrant accused. Instead, Parliament legislated a measure in 1275 called prison forte $t$ dure, whereby "notorious felons who were openly of ill fame and would not put themselves upon [local juries would] be kept in strong and hard prison as refusing to stand to the common law of the land. ${ }^{377}$ Prison forte et dure required the offender to be shackled in irons and placed on the floor of the prison. The offender would receive meager amounts of bread and water and would remain in the prison until he accepted trial by jury. Unfortunately, the Latin used in the statute was soon misunderstood and the prison was read as peine (punishment). Consequently by the 1300 s, peine forte et dure involved placing the accused between two boards and piling weights upon him until he accepted trial by jury or expired. Some accused with little hope of acquittal chose this horrible fate rather than be subjected to trial by jury so that they could die unconvicted and thus save their dependants from forfeiture of their property, a consequence that used to follow the conviction of a felon. The last instance of peine forte et dure occurred in $1741 .^{38}$

It is readily apparent that the emergence of the criminal trial jury in England is causally connected to the demise of the ordeal. Trial by jury was chosen as a replacement because by 1215 , criminal juries were already issuing opinions approximating verdicts on guilt or innocence. All that was required to fill the void left by the forbidding of the ordeal was to recognize that these verdicts were final rather than medial. This recognition could be accomplished, but only if the accused consented to accept the verdict of the trial jury as dispositive. This consent was required because, unlike the ordeal, the trial jury's verdict was a judgment of men, not God. Nevertheless, the verdict of the criminal trial jury was generally accorded the same degree of inscrutability as that associated with the verdict of the ordeal.

$1 \quad$ Sir Frederick Pollock \& Frederic William Maitland, The Hisiony of English Law Before the Time of Edward I, 2d ed. (1898; reprint, Cambridge: Cambridge University Press, 1923) vol. 2 at 651.

in

lbid. at 31 .
Baker, supra note 16 at 509. As late as 1772, the accused's silence when asked if he would accept trial by jury resulted in the accused's automatic conviction (see Stat. 12 Geo. III, c. 20). It was not until 1827 that a refusal to plead began to be treated as equivalent to a not guilty plea (see Stat. $7 \& 8 \mathrm{Geo}$. IV, c. 
Thus, in the beginning and for at least a little while, justices tended not to question the verdicts of trial juries nor did they often require jurors to give reasons for their decisions. ${ }^{39}$

In the second part of this article, I will explore the reasons that justices refrained from questioning the verdicts of juries during the early life of the criminal trial jury. Moreover, I will explain why the inscrutability of jury verdicts was destined to disappear and then reemerge in the late eighteenth century.

\section{The Changing Nature of the Criminal Trial Jury in England FROM TIE 1200 S TO THE 1800 S}

\section{A. THE SELF-INFORMED JUROR}

Until recently, it was a commonly held theory that, until the late fifteenth century, the criminal trial jury was a self-informing institution. In other words, presentation in the form of witness evidence was believed to form no part of the early medieval trial. Jurors investigated allegations of wrongdoing and came to the trial ready to report what they had found. Trial juries were composed of men drawn from the immediate neighborhood where the crime occurred. ${ }^{40}$ This requirement was meant to produce jurors who already knew or could easily find out what had occurred and who was responsible. The impressive local knowledge of many early criminal trial juries has been well documented. ${ }^{41}$

Nevertheless, the orthodox view of the criminal trial jury as a solely self-informing medieval institution has come under attack. Edward Powell has uncovered evidence that, by the 1400s, most trial jurors did not live in the neighborhood where the offence occurred. ${ }^{42}$ He argues that, as a result, jurors would have found it too difficult to apprise themselves of the facts of the offence charged and so evidence in some form must have been presented to them at the trial. ${ }^{33}$

This seems to have been true except in cases involving verdicts of self-defence. As Green recounts: "Here the judges had some leeway in testing verdicts. for the jury had to ... Iprovide an account of the events] ... that justified the special verdict: a simple "not guilty" or "self-defence" would not do" (Green. Verdict, supra note 5 at 67).

It was not until 1919 that women could serve on a criminal trial jury (sec the Sex Disqualification (Removal) Act, 1919 (U.K.), 9 \& 10 Geo. 5. c. 71). However, prior to 1919 women were the only individuals who could serve on the jury of matrons. The function of this jury was to determine whether a convicted woman who pleaded that she was pregnant in order to first delay and then later prevent her execution was truly pregnant. For more information on this type of jury. which existed until 1931, see Judy M. Cornett, "Hoodwink'd by Custom: The Exclusion of Women From Juries in EighteenthCentury English Law and Literature" (1997) 4 Wm. \& Mary J. Women \& L. 1 at 17-34: and J.C. Oldham, "On Pleading the Belly: A History of the Jury of Matrons" (1985) 6 Criminal Justice History 1. Until the twenticth century it was only men between 21 and 60 years of age with the requisite property qualifications who could sit as members of a criminal trial jury. The ohjectives and effects of the property qualifications for jurors will be discussed later.

" For example, Pugh, while examining court records from a London court during a ten-year span in the thirteenth century, found that on over 60 necasions juries acquitted a suspect and then went on to inculpate other persons tor the offences (Ralph B. Pugh, Some Reflections of a Medieval Criminologist (London: Oxford Universily Press. 1973) at 15)

"2 Edward Powell, "Jury Trial at Gaol Delivery in the Late Middle Ages: The Midland Circuit. 1400-1429" in Cockburn \& Green. supra note 25, 78. 
Reactions to the evidence gathered by Powell and the conclusions that he draws from it have been varied. Thomas A. Green acknowledges that Powell is correct to push back the timeline for the presence of testimonial evidence in criminal matters from the late fifteenth century to the early fifteenth century. ${ }^{44}$ But since Powell's evidence shows that only 15 percent of cases had juries with no members from the same hundred as the scene of the crime, most juries could still be, in large part, self-informing through the efforts of those jurors who lived close to the locale of the offence. ${ }^{45}$ Thus Green agrees with Powell that the criminal trial jury was no longer solely self-informing by 1400 but insists that throughout much of the medieval period, the jury was, at least in large part, primarily self-informing. ${ }^{46} \mathrm{~J}$.G. Bellamy has expressed doubts about Powell's conclusion that trial jurors who did not reside in the same hundred wherein the offence occurred would have had difficulty obtaining information about the offence. Bellamy stresses the fact that since many of these trial jurors were local officeholders such as coroners and village constables, they would have been in a position to obtain information about the offence. ${ }^{47}$ Those jurors who did not reside in the relevant hundred and did not hold a prominent office in the community wherein the offence was committed may still have been knowledgeable about it. As Bellamy explains:

Their knowledge might have derived from commercial dealings with the suspect, or being involved in his pursuit and arrest, or living near his home.... Until the homes, places of oflence and arrest of the suspecis have been plotted against the jurors' residences, movement patterns, commercial connections, and the area where they exercised any non-legal office, it is too early to come to firm conclusions about their knowledge of the crimes and the suspect felons who appeared before them. ${ }^{48}$

Whether or not the criminal trial jury was ever solely self-informing is unclear. Nevertheless, the prevailing current theory is that this institution was at least largely selfinforming but that its self-informing nature was slowly eroded by the growing presence of witnesses giving oral evidence during criminal trials.

In light of the self-informing nature of the early criminal trial jury, the reason why the bench rarely questioned jury verdicts becomes clear. For the most part, judges were not privy to the information and evidence relied upon by criminal trial juries. Consequently, there was little prospect of judges and juries coming to different conclusions pertaining to the proper outcome of trials. The impetus for judges to begin questioning jury verdicts was simply absent.

\section{B. THE RISE OF THE WITNESS TRIAL}

The transformation from juries that brought the majority of the key information with them into court to juries that relied mainly on the evidence presented to them in court is not well understood in terms of its causes or its timing. At least one author has advanced the

Thomas A. Green, "A Retrospective on the Criminal Trial Jury, 1200-1800" in Cockburn \& Green. supra note 25,358 at 374 .

lbid. at 368,370 .

lbid. at 374.

J.G. Bellamy, The Criminal Triat in Later Medieval England: Felory Before the Courts from Edward Ito the Sixteenth Century (Toronto: University of Toronto Press, 1998) at 112.

Ibid. 
hypothesis that the self-informing system presupposed a static populace and forms of communal agricultural organization whose dissolution probably began with the vast social dislocations of the Black Death of $1348-49 .{ }^{49}$ What is known is that, in all likelihood by the later fifteenth century, and certainly by the sixteenth century, jurors were more dependent on evidence presented to them than on information they themselves had gathered. ${ }^{30}$ Yet it was not until the second half of the eighteenth century that jurors were precluded from relying upon evidence related to them out of court..1

The appearance of witnesses at criminal trials may also be related to changes in the composition of the criminal trial jury. In the thirteenth century it was common for many of those who served on the accused's presenting jury to subsequently participate on the trial jury. This overlap in membership between the two juries facilitated the self-informing process engaged in by jurors. Despite the fact that recent evidence does not suggest a noticeable bias towards conviction when the majority of the trial jurors had also brought the accusation, ${ }^{52}$ presumably it began to be felt that having the same jurors sit on both juries may work an injustice to the accused. In 1352, legislation was passed allowing an accused to challenge any presenting jurors who were to sit on his trial jury."

In the fourteenth century and continuing to this day, a "challenge" was a means by which either the prosecutor or the accused could prevent potential jurors from sitting on the jury. One type of challenge utilized by accused was called the "peremptory challenge." It did not require the challenging party to give a reason for the challenge; when the accused used a peremptory challenge the potential juror was automatically eliminated from the jury. In the fourteenth century, the common law permitted an accused charged with a felony to raise 35 peremptory challenges. ${ }^{{ }^{4}}$

By the early 1300 s, although the prosecutor's peremptory challenges were abolished, he could utilize the stand-aside, whereby the swearing in of prospective jurors that the prosecutor did not want on the jury could be postponed until the entire panel had been exhausted. Only if a jury had not been chosen by the end of the panel, would resort be made to the stood-aside jurors. Because the number of stand-asides afforded to the prosecutor was unlimited, a large jury pool provided a more powerful method of excluding jurors than the peremptory challenge."s

Moreover, jurors could also be challenged "for cause." In a challenge for cause, the partiality or personal characteristics of the juror could pre-empt his membership on the jury.

John H. Langbein, The Origins of Adversary Criminal Trial (Oxford: Oxford University Press, 2003) at 64 [Langbcin, Origins].

John H. Langbein, "The Criminal Trial before the Lawyers" (1978) 45 U. Chicago L. Rev. 263 at 299 [Langbein, "Criminal Trial"].

Langbein, Origins, supra note 49 at 320.

See Anthony Musson, "Twelve Good Men and True? The Character of Early Fourteenth-Century Juries" (1997) 15 L..H.R. 115 at 137.

(I352), 25 Edward III st. 5, c. 3 (SR, vol. I, 320).

J.B. Post, "Jury Lists and Juries in the Late Fourteenth Century" in Cockburn \& Green, supra note 25. 65 at 71.

R. Blake Brown. "Challenges for Cause, Stand-Asides, and Peremptory Challenges in the Nineteenth Century" (2000) 38 Osgoode Hall L.J. 453 at 459 [Brown. "Challenges for Cause"]. 
For example, the challenge to indictors to prevent them from sitting on the trial jury was a challenge for cause. Because jurors were expected to be at least largely self-informing, challenges were not intended to exclude jurors who had prior knowledge of the events in question. Rather, challenges for cause sought to prevent those jurors who did not meet the proper residence ${ }^{56}$ and property qualifications, or who had a prior relationship with one of the parties, from sitting on the jury. For both sides, the number of challenges for cause was unlimited. In addition, the prosecutor did not have to challenge for cause any stood-aside jurors until the entire panel had been exhausted. Because the number of peremptory challenges for the accused was limited, accused could challenge for cause, await a decision on the challenge and then, if the decision was unfavorable, use the peremptory challenge to excuse the prospective juror.

The last type of challenge, but one that was more rarely resorted to than peremptory challenges or challenges for cause, was a challenge to the "array." A challenge to the array was a challenge to the entire panel of summoned jurors on the basis that the official responsible for calling the jurors, usually the sheriff, acted out of bias. The success rate of these challenges during medieval times is uncertain. ${ }^{37}$ What is clear is that by the end of the nineteenth century, these challenges had become so unsuccessful that there was a de facto extinguishment of array challenges. ${ }^{38}$

Although there is evidence that in the early part of the fourteenth century challenges of any kind were not infrequent, ${ }^{39}$ there is no such evidence for the latter part of the fourteenth century. ${ }^{60}$ The disappearance of the challenge has been attributed by some scholars to the decline in overlapping membership between the presenting and trial juries brought about by the statute of $1352 .^{61}$

Even into the eighteenth century, challenges and stand-asides were uncommon. Why this was so is uncertain. John Baker has speculated: "Either [the parties] did not know the jurors or anything against them, or did not act quickly enough, or were simply too over-awed to understand what the clerk had told them." ${ }^{22}$ Baker's explanation is plausible because the effective exercise of challenge rights depended upon knowing the background of prospective jurors before trial. But there was no right to know which individuals would constitute the jury panel prior to trial except, after 1696, for trials involving treason. John H. Langbein suggests

*. Although originally jurors were to reside in the neighbourhood in which the alleged offences wero committed, by the late sixteenth century residence in the county in which the alleged offences occurred was the only residential requirement for jurors (see P.G. Lawson, "Lawless Juries? The Composition and Behavior of Hertfordshire Juries, 1573-1624" in Cockburn \& Green, supra note 25, 117 at 123). Jury packing was a standard practice pertaining to trials with a political overtone, such as treason trials. Nevertheless, some historians doubt that jury packing was a common phenomenon in routine criminal cases (see, for example, J.S. Cockburn, A History of English Assizes, 1558-1714 (Cambridgc: Cambridge University Press, 1972) at 1(6-20) [Cockburn, History of English Assizes].

s* For more information on the decline of array challenges in England during the nineteenth century, sec R. Blake Brown. “A Delusion, a Mockery, and a Snare: Array Challenges and Jury Selection in England and Ireland, 1800-1850" (2004) 39 Canadian Journal of History I.

5. See Musson, supra note 52 at 133.

eat See P'ost, supra note 54.

il See, for example, Musson, supra note 52; statule at note 53 .

n: John H. Baker, "Criminal Courts and Procedure at Common Law 1550-1800" in J.S. Cockburn, ed., Crime in England 1550-1800 (Princeton: Princeton Universily Press, 1977) 21 at 23. 
that accused may have feared that exercising their challenge rights without weighty cause would be resented by the court and by the substitute jurors ultimately impanelled to try them. ${ }^{63}$

In the eighteenth century certain developments limited the effective use of challenges for cause, a situation that was to become exacerbated in the nineteenth century. Traditionally, there were two methods that could be used to demonstrate a prospective juror's partiality or lack of relevant qualification in a challenge for cause. The first method was to offer witnesses, and the second method was to question the prospective juror. However, by the late eighteenth century, the rule had been expounded that jurors could not be asked any question that might cause them any shame, including whether or not they had been so rash as to declare an opinion as to the correct outcome of the case prior to trial. ${ }^{64}$ Thus, the most common eighteenth century manner of demonstrating a juror's partiality was through the production of witnesses. Even one witness testifying that a juror had expressed an opinion as to the proper outcome of the case prior to trial was sufficient to make out the challenge for cause. Nevertheless, in the 1821 case of $R$. $v$. Edmonds, ${ }^{\text {os }}$ the court held that jurors could form and express opinions about the proper outcome of the trial as long as that belief was not based on ill will towards the accused. Consequently, the burden was placed on the accused to demonstrate personal ill will between him or her and those prospective jurors who expressed pre-trial opinions pertaining to guilt, and this burden had to be met without the benefit of questioning those prospective jurors. As a result, challenges for cause remained uncommon in English courtrooms. Indeed, in his 1966 study of the English jury system, Patrick Devlin declared that challenges for cause in England were obsolete, as the last reported case dealing with this type of challenge was 90 years old. ${ }^{.6}$

Nevertheless, it could be argued that regular challenges made in the early part of the fourteenth century led to the exclusion of many of those individuals from trial juries who were likely to favour either the prosecutor or the accused, as well as many of those who knew something of the matter, such as the indictors of the accused. Because of the success of these challenges, officials impanelling juries may have ceased the practice of drawing jury panels composed of the friends and kin of the accused or the alleged victim and/or the accused's indictors. Yet these individuals were in ideal positions to know something of the matters at issue. The trial jurors who were chosen instead of them may not have known very much about the case when they arrived in court. Consequently, the growth and success of the challenge in the early fourteenth century may very well have been a factor in the emergence of the witness at criminal trials..$^{67}$

John H. Langbein. "The English Criminal Trial Jury on the Eve of the French Revolution" in Antonio Schioppa, ed., The Trial Jury in England, France, Germamy 1700-1900 (Berlin: Duncker \& Humblot. 1987) 13 at 28 [Langbein, "English Criminal Trial Jury"]. Brown, "Challenges for Cause," supra note 55 at 461-62.

[1814-23] All E.R. 241.

Patrick Devlin, Trial by Jury (London: Methuen. 1966) at 29. For an explanation of why the English judiciary heightened the burden on the accused to make out challenges for cause, see Brown. "Challenges for Cause," supra nole 55. 
The need to resort to witnesses in criminal trials may also be related to another factor. By the 1400 s, a single jury was often expected to return verdicts on a number of cases in one sitting of the court, and many of these alleged offences occurred in different parts of the county ${ }^{68}$ At this time, it would have been exceedingly difficult for the jurors to travel to each of the communities in which the offences occurred in order to investigate the matters. Hence the need for juries to be informed via witness evidence.

A mid-sixteenth century development pertaining to the state's role in matters of law enforcement and the prosecution of alleged offenders may also assist in explaining how witness evidence began to become a more regular and relied upon phenomenon. Until the second quarter of the nineteenth century, there was no full-time police force to investigate crime and until the late nineteenth century, there was not even a limited public prosecution service whose lawyers could prosecute offenders. By the 1400 s, appeals of felony were becoming a rarity and the role of the presenting jury had changed. No longer did it go out and investigate allegations of wrongdoing. Instead, alleged victims of crime and the witnesses brought by them gave evidence before the presenting jury and, based on this evidence, the presenting jury determined whether there was enough evidence for the accused to stand trial. If the accused was indicted by the presenting jury (committed to stand trial), the alleged victim would have to arrange for his or her witnesses to give evidence at the trial. The only assistance given to alleged victims in terms of tracking down witnesses was by part-time village constables. However in 1555, the Marian Committal Statute was passed. ${ }^{69}$ Among other things, this statute enabled Justices of the Peace to conduct pre-trial examinations of the accused and, if any incriminating statements were made by the accused, the statements could be admitted into evidence at the trial. This statute also required the Justice of the Peace to bind over, or issue an order, compelling the victim and those accusing witnesses whose testimony would be "material to prove ... the Felony" to attend the trial and to testify against the accused. Consequently, although the means to compel defence witnesses to attend in court did not exist until $1702,{ }^{70}$ from 1555 onwards prosecution witnesses, in order to avoid being prosecuted themselves for non-attendance, began appearing in greater numbers to testify in court.

\section{THE INCOMPETENT JUROR}

From at least the mid-sixteenth century until well into the nineteenth century, commentators often criticized the jury as being composed of individuals who were not up to the challenge and demands of the job. Nevertheless, the evidence suggests otherwise. The vast majority of jurors had some experience of local office - in fact, many jurors held prominent public offices, such as those of village constable or coroner, in their local communities. Thus, if jurors were easily misled it was not for lack of experience with making group decisions affecting the poorer members of the local community. ${ }^{71}$ 
Yet other historians have questioned how useful histories of local administrative offices were in the preparation of jurors for their tasks. To these historians, what constitutes more cogent evidence that jurors were well suited to the task of rendering verdicts in criminal cases was the fact that a significant number of jurors were, beginning in the mid-1500s, called upon to serve as jurors year after year in successive sessions of the court. J.S. Cockburn recounts how two individuals had a combined jury service that spanned 27 years, during which they tried, often as foremen, almost 700 prisoners. $^{72}$

The influence of these experienced jurors was considerable. Until the mid-eighteenth century, the average duration of a trial, including time for jury deliberations, was approximately 30 minutes. ${ }^{33}$ Therefore, juries rarely spent more than a few minutes deliberating on any one case. It has been postulated that the brief deliberations and the rarity of hung juries can both be attributed to the acquiescence of the majority of jurors in the verdict arrived at by a few dominant figures on the jury, probably the few experienced jurors who sat near and concurred with the foreman, and who could make sense of the rapid dissemination of information that occurred during the trial. ${ }^{94}$

\section{THE CORRUPT JUROR}

Another constant criticism of jurors was that they were easily corruptible. A rule withholding food and drink from jurors after they were charged (given directions on the law pertaining to the case(s) before them) appeared in certain English treatises in the $1290 \mathrm{~s}^{7}$ It was conceived, in part, to combat the improper inducement of jurors. The rule was broadened in 1346 to prevent jurors from eating or drinking not just during deliberations but also at any time after they were sworn, ${ }^{76}$ and it continued in force until $1870 .{ }^{17}$ The multiple objectives and effects of this rule are described by David J. Seipp as follows:

The original motivation for the rule forbidding food and drink to jurors was not merely to prevent petty bribery [via one of the parties wining and dining the jurors], not merely to keep them sober and awake, but rather to force them to agree on a verdict. Even before the common law required unanimous verdicts, justices were locking up jurors without food or drink in order to compel the jurors to agree... [I]f one juror lad some food or drink after they were sworn, ... that one could hold out against liunger and thirst longer than the others, and so compel the rest to agree with his view of the case... [L]etting some jurors have sustenance while depriving the rest would skew the result... [A] juror who knew the truth to be with one party might be forced by hunger and thirst to join in a verdict against his conscience... Hunger and thirst would overcome a dissenting juror's scruples. As Alexander Pope wrote in 1714, "wretches hang, that jurymen may dine." With this rule against food and drink in mind, other features of the late medieval trial, such as the remarkable speed of the proceedings, make more sense... A party who excessively prolonged the time that jurors must spend in coun

J.S. Cockburn, "Twelve Silly Men? The Trial Jury at Assizes. 1560-1670" in Cockburn \& Green. supre note 25,158 at 170 [Cockburn, "Twelve Silly Men"].

Langbein. Origins, supra note 49 at 17.

J.M. Beattic, Crime and the Courts in England 1660-1800 (Princeton: Princeton University Press. 1986) at 397 [Beattic, Crime and the Courts].

David J. Seipp, "Jurors, Evidences and the Tempest of $1499 "$ in John W. Caims \& Grant Mcl.eod. eds. The Dearest Birth Right of the People of England: The Jun' in the History of the Common l.an (Portland: Hart Publishing. 2002) 75 at 86.

(1346), Y.B. Trin. 20 Edw. III, pl. 8, I RS 487.

W.R. Cornish, The Jury (London: Allen Lane The Penguin Press, 1968) at 70 
without food and drink would not have been popular among the jury... In court, jurors forbidden food and drink from the moment they were swom until after they came back with their verdict, had reason to want the parties ... to get through their challenges and arguments, the clerk to read out the issue, and justices to charge them - all as quickly as possible. The rule against food and drink kept common law litigation humming along with almost indecent haste. By this means, a pair of justices could get through several trials in a single day. ${ }^{78}$

In this quotation, Seipp refers to the fact that it was not always the case that all 12 jurors had to agree on a verdict before it was accepted by the court. It was not until 1367 that it was decided that majority verdicts would not suffice and that unanimity was required. ${ }^{79}$

Although the historical record does not reveal a complete absence of evidence pertaining to the bribing of jurors, there is reason to believe that, at least in relation to criminal matters, jurors were not often swayed by bribes. Since the late thirteenth century, there had been property qualifications for jurors, which could only be met if the individuals owned land. Although the property holding requirements varied from century to century, ${ }^{80}$ their effect was always to exclude large proportions of the populace from eligibility for jury service. By the eighteenth century 75 percent of adult males were too poor, even if their entire wealth was in land, to qualify as jurors. ${ }^{81}$ Because those who fulfilled the property requirements of jury service were relatively wealthy, it was thought that such individuals would be more impervious to the temptation of selling their verdicts. ${ }^{82}$ Allegations have reoccurred throughout the centuries that sheriffs and other officials charged with impanelling juries would often be bribed into overlooking wealthy potential jurors by those same wealthy potential jurors in favour of certain individuals who did not meet the requisite property qualifications or barely did so. ${ }^{83}$ Although such incidents undoubtedly did occur, and some individuals were likely reluctant to serve on juries, and the wealthiest gentry often avoided jury service, the evidence suggests that the vast majority of jurors who were summoned and/or did serve easily met the high property qualifications for jurors. ${ }^{84}$ Moreover, like today,

Seipp, supra note 75 at 88-89.

Holdsworth, supra nole 8 at 318 .

For the jury qualifications established by Parliament, including the property holding requirements, from the thireenth to the eighteenth century, see James C. Oldham, "The Origins of the Special Jury" (1983) 50 U. Chicago L. Rev. 137 at 214-2I.

Douglas Hay, "The Class Composition of the Palladium of Liberty: Trial Jurors in the liighteenth Century" in Cockbum \& Green, supra note 25, 305 at 315.

In the eighteenth century there was an equation of social class, which was measured by real property ownership, with intelligence or education; sec ibid. at 307.

See the examples recounted in Stephen Roberts, "Jury Vetting in the 17 th Century" (1982) 32 History Today 25 at 28.

See, for example, the evidence cited in Lawson, supra note 56; Hay, supra nole 81; Cockburn. "Twelve Silly Men," supra note 72; J.M. Beattie, "London Juries in the 1690 s" in Cockburn \& Green, supra note 25, 214 [Beattic, "London Juries"]; and King, supra note 71 . Lawson cites data that suggests that those summoned for jury duty in the sixteenth and seventeenth centuries, at least in some areas, rarely failed to show up for service, while Cockburn cites evidence showing a high rate of summoned juror absenteeism during this period. It does appear that the fines imposed upon absentee summoned jurors for non-appearance were trifling compared to the socio-economic status of most of the summoned jurors. Thus, there was little financial incentive to appear for jury duty. Indeed there were financial disincentives pertaining to the fulfilling of one's jury service. Until 1671, jurors could be fined for finding against the weight of the evidence. Moreover, jurors had to pay their own travel and accommodation expenses pertaining to jury service and, until 1949, al least common jurors did nol receive any remuneration for their service. In cases of less serious criminal offences or misdemeanours, the accused or the prosecutor could request a special jury whose members met the normal propenty 
those accused of criminal offences tended to be drawn from the lower socio-economic strata of society. It is unlikely these accused would be able to afford to bribe jurors.

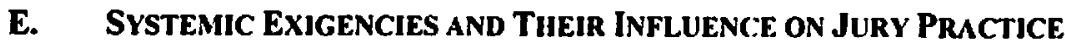

Changes in the manner in which juries were created also led to reforms in the mode of jury deliberation. Prior to 1650, a jury would usually hear a batch of cases and then retire to deliberate on them all. Eventually, the jurors would return to court to deliver their set of verdicts. Outside of London, travelling judges visited provincial towns and held court there at regular intervals. These judges were on tight schedules and could not afford for the court to remain idle while a jury deliberated on a series of cases. Thus, when one trial jury retired to deliberate, a second group of 12 men were sworn in if the court's business was not to be brought to a standstill while the first jury deliberated. Sometimes a succession of juries was required, with each jury being composed of individuals who did not serve on the other juries. Under this system sheriffs began to find it difficult to find a sufficient number of qualified jurors to deal with all the cases. Consequently, the method of requiring a series of essentially separate jury panels to follow each other was replaced in the middle of the seventeenth century. In the new system, the successive panels were largely made up of jurors who had served earlier in the session. The new system allowed for a significant reduction in the total number of individuals required for jury service and it ensured that successive panels, at the very least, were predominantly if not exclusively composed of jurors who had previous criminal trial experience. ${ }^{85}$

However, this new system was to soon undergo a major change as well. The new system required at least two separate juries to prevent the court's operation from becoming stalled. When one jury went out to deliberate on its group of cases, the other would need to hear its batch of cases in court, and when it retired to deliberate the first jury would hopefully be in a position to hear a further set of cases, and so on. Even having two complete and separate criminal trial juries for a session of the court was becoming problematic as a growing list of

qualifications but each of whom were of the rank of esquire or above. In the nineteenth century, special jurors received remuneration consisting of one guinea for each case they tried (see David Bentley. English Criminal Justice in the Ninereenth Century (London: Hambledon Press, 1998) at 89, 94). Cockburn notes that the practice of recruiting talesmen to fill jury vacancies was quite common by the sixteenth and seventeenth centuries. Talesmen were individuals who were not summoned for jury duty but who happened to be bystanders in court. However, Cockburn observes that such bystanders were unlikely to include many of the labouring poor, who had little reason to attend court and few means to afford to be able to do so, and whose ignorance and susceptibility to bribery so appalled the critics of the jury system. Indeed, Hay cites later evidence showing that the few talesmen who were recruited in the eighteenth century met the property qualifications for summoned jurors. Consequently even if there was a significant problem pertaining to summoned juror absentecism during some time periods in soint counties. the practice of relying on talcsmen to till juries did not result in a de facto dilution of the property qualifications for juries. In addition, although Cockburn maintains that service on trial juries was unpopular, other historians such as Beattic argue that it is possible that many jurors, who already held positions of governance in their communities, viewed jury service as an aspect of local governance that they willingly took on as a means of participating in the maintenance of order in their neighbourhoods. 
exempted occupations pertaining to jury duty came into recognition. ${ }^{86}$ In the late seventeenth century criminal trial juries outside London began to deliberate in open court on each case as it was concluded and announce the verdict before hearing evidence on the next case ${ }^{87} \mathrm{As}$ a result, fewer than 24 jurors were needed for any single session of the criminal court. Eventually, the practice of jurors rendering verdicts at the conclusion of each case and deliberating in open court spread from the counties back to London and, in 1738, the London courts adopted the provincial practice. ${ }^{88}$

This reform spurred further changes. Jurors began to sit together in court in order to facilitate their deliberations. When jurors heard a batch of cases and retired to deliberate on them all before rendering a set of verdicts, the jurors were expected to take notes during the trial so that they could differentiate the evidence heard in one case from the evidence heard in another case. ${ }^{89}$ Thus, it is possible that any decline in later juror note-taking during trials is attributable, in part, to the fact that jurors no longer needed to separate the evidence they heard as their verdicts were entered at the conclusion of each trial.

Although the system of delivering verdicts at the conclusion of each case continued, the practice of the juries deliberating in open court did not. Soon it became apparent that the spectators who made their presence and opinions known in the small cramped courts of the eighteenth and nineteenth centuries were influencing jurors during their deliberations. This fact, coupled with the increasing length of criminal trials in the twentieth century, which was largely attributable to the increased complexity of the law of evidence and the growing presence of lawyers at criminal trials, lent support to the modern practice of juries retiring from the courtroom to deliberate. Yet even this practice did not ensure that jurors would be free from intimidation during their deliberations. Inadequate accommodation at courthouses frequently forced juries to deliberate in places such as alehouses, which facilitated the public's access to jurors. ${ }^{20}$ It was only in the nineteenth and twentieth centuries that courthouses began to regularly contain secure jury deliberation rooms.

The first laws of criminal evidence initiated by the eighteenth century English bench were administered very differently than those laws are today. When judges determined issues of admissibility of evidence in the eighteenth century, they did so in the presence of the jury. So in the case of evidence that the court ruled inadmissible, the members of the jury would be directed to ignore the evidence that they had, perhaps moments ago, heard. Today the normal course is for a judge to hear the evidence and determine its admissibility in the absence of the jury. Consequently if the evidence is deemed inadmissible, the jury will never hear it.

The lawyer-conducted criminal trial appeared relatively late in English legal history. Although prosecuting counsel was permitted, it was rare for lawyers to be retained by the

By the end of the eighteentli century the list of exempted occupations included apothecaries, clergymen, altorneys, coroners, registered stamen, foresters and butchers (Langbein. "Englislı Criminal Trial Jury," supra note 63 at 25 ). 
alleged victims in any criminal actions, and the state did not usually retain lawyers to conduct prosecutions except in the case of charges of treason. To compensate for the presence of lawyers prosecuting the case for the Crown in matters of treason, in 1696, accused persons were given the right to be represented by defence counsel for the first time, but only when defending against this type of felony. ${ }^{91}$ In the early eighteenth century, more alleged victims of crime began to retain lawyers to prepare and conduct criminal prosecutions, and Parliament enacted a series of statutes that offered monetary awards to persons who assisted in the apprehension and conviction of offenders. ${ }^{92}$ In the 1730 s, the same process of "evening up" for prosecution advantages in relation to treason trials led the courts to extend the assistance of defence counsel to persons accused of ordinary felony. ${ }^{93}$ However, it was not until the 1780s that defence counsel began to appear more regularly and even by this date, defence counsel was restricted to examining and cross-examining witnesses. Finally, in 1836, defence counsel was allowed to address the jury by presenting the accused's version of events and by providing commentary on the evidence directly to the jurors. ${ }^{94}$

The lawyer-free trial that was conducted from the fifteenth until well into the eighteenth century has been called the "altercation trial," and its successor is called the "adversarial trial." Altercation trials had a wandering quality that resembled ordinary discourse - the judge often questioned the participants, examining and cross-examining them, to fill out the testimony they volunteered. ${ }^{93}$ The formless nature of a typical altercation trial is illustrated by the following account of the 1647 trial of Sir Edward Mosely for rape:

As the vietim was narrating her account of the events. Mosely interrupted her with a long question that served to give his version of the events. The judge then began exploring the implications of what Mosely had said, asking the victim's husband about Mosely's allegations, to which question the victim rather than the husband replied. Later in the trial Mosely introduced a defence witness. Kilvert, who was about to testify lhat the victim had bragged to him of having previously threatened to bring a trumped-up rape case aguinst an innocent clergyman in order to extort hush money. Before Kilvert could speak, the victim intervened to declare that "I hope no body will believe what this knave Kilvert will say, for he is a knave known to all the court, and all that hear him." $\%$

The unstructured nature of the altercation trial often meant that there was no clear division of the trial into prosecution and defence cases. Consequently, the jury was not instructed to focus on whether the prosecution had met its production burden. The accused was expected to give his version of the event, and the failure to do so was understood to virtually ensure conviction. The assumption was not that the accused was innocent until the Crown proved its case beyond a reasonable doubt, but that if the accused was innocent he ought to be able to demonstrate it for the jury by the quality and character of his reply to the prosecutor's

Treason Trials Act 1696 (U.K.), 7 Wil. 3, c. 3.

Sec e.g. 5 Anne. c. 31, s. 1 (1706); 6 Geo. I., c. 23, s. 8 (1719); and I 4 Geo II., c. 6. s. 2 (1741). Langbein, Origins, supra note 49 at 102.

For a comprehensive discussion and analysis of these developments, see David J.A. Cairns, Advocacy and the Making of the Adversarial Criminal Trial 1800-1865 (Oxford: Clarendon Press, 1998): and Langbein, ibid.

Langbein, ibid. at 253.

The Arraignment and Acquitral of Sir Edward Mosely (London. 1647). reprinted in 6 Harleian Miscellamy 46 (London 1810 ed.) (1st edition, London 1744-6). 
evidence. ${ }^{97}$ Indeed, the "beyond a reasonable doubt" burden of proof did not emerge until the later eighteenth century. ${ }^{98}$

The unstructured nature of the altercation trial also allowed the jury to play a more active role than the jury was to assume in adversarial trials. Jurors joined in the unstructured conversation by sometimes directly questioning witnesses, making observations in open court as witnesses testified and asking for further witnesses to be summoned. ${ }^{\text {? }}$

By the last quarter of the eighteenth century, as the initiative in adducing fact passed to counsel and the adversarial trial was born, the powers that the jury enjoyed under the altercation trial were curtailed. As Langbein notes:

Adversary criminal trial did not leave room for jurors to participate in framing the inquiry, for the same reason it pressured the judge 10 stand down from such work. The system of adversary presentation of the proofs was antithetical to nonadversary initiatives in adducing the facts, whether from judge or from jurors. The lawyerconducted trial was no longer centered on the questions that, however clumsily, had been at the center of a contested altercation trial, namely, what really happened. and did the accused really do it. Adversary procedure refocused the trial on a different question - whether defence counsel had succeeded in raising sufficient doubt about the strength of the prosecution case. Defence counsel did not want other participants cluttering that inquiry with other questions, especially with questions about the truth. The age of the altercation trial - trial as an open discussion among the participants - was past. ${ }^{100}$

Consequently, the adversarial trial either totally or substantially eliminated the practice of jurors questioning witnesses, requesting further witnesses to be calied, and commenting on witnesses and their evidence in open court during the trial.

However, even under the altercation trial the jury suffered some constraints. Because judges heard the same witnesses as the jurors, judges began to exercise significant powers of control over the jury to prevent and/or correct what they saw as jury error.

One power that judges routinely exercised was expressing the bench's view of the merits of the case to the jury before the jury deliberated. Even today the power of judges to comment on the merits of a case still exists in England, albeit in adversarial trials that power has been moderated. Judges now have to ensure that jurors know it is their own view of the facts, and not the judge's perspective, that is to be determinative. And judges must also ensure that jurors are free to give whatever weight they choose to the judge's opinion. ${ }^{101}$

Beattie, Crime and the Courts, supra note 74 at 341.

Langbein. Origins, supra note 49 at 262.

Ibid. at 319.

Ibid. at 321. For an in-depth discussion of how the "lawyerization" of the criminal trial obliuscited as opposed to promoted the trutl,, see Langhein. ibid. at 258-84, 291-300, 306-18, 331-43. II essence. langbein asserts that, by permilting abusive and misleading cross-examination, the coaching of witnesses and the concealment of unfavorable evidence by counsel, the adversarial dynamic distorted the fact-finding function of the trial. This distortion was exacerbated because not everyone cuuld afford to hire barristers and solicitors to gather and present evidence.

R. v. Lawrence [1982] A.C. 510 (Ct. Crim. App.). 
Until the 1670s, judges could buttress the force of their judicial commentary as to the merits of the case through their power to fine jurors for returning verdicts against the weight of the evidence. However, that latter power was lost as a result of the famous decision in Bushel's Case. ${ }^{102}$

The background to this case raises issues of religious freedom and jury nullification. ${ }^{103}$ This case was decided at a time when the English state had become increasingly intolerant of Quakers. William Penn, a young aristocratic Quaker, wished to deliver a sermon at the Quaker's meeting house, but he discovered that city authorities had padlocked the entrance to it. Barred from his church, Penn, assisted by another Quaker, William Mead, spoke in the street. As Penn was speaking, a crowd of several hundred people gathered, and constables arrested Penn and Mead for causing an unlawful assembly and disturbing the peace. Penn did not deny preaching to the crowd and Mead did not refute the accusation that he assisted Penn. Far from it, they freely admitted such actions in open court. However Penn appealed to the jury to acquit them in the face of the unjust laws under which they were being subjected to tyrannical prosecutions. Despite repeated threats to the jurors emanating from the bench and numerous directions for the jury to redeliberate, the jury refused to convict Penn and Mead and, in the end, the bench had to accept the "not guilty" verdicts. But the bench proceeded to order fines against the jurors accompanied by a directive that the jurors were to remain imprisoned until the fines were paid. Eight of the jurors promptly paid the fines. However, the foreman of the jury, Edward Bushel, and three others refused to pay. Instead they retained counsel and sued in the Court of Common Pleas for their freedom and remission of their fines.

A year after they were released on bail, Vaughan C.J. wrote the judgment in Bushel's Case. The Chief Justice held to the orthodox view that is still subscribed to throughout the Anglo-American legal world - that the law is the domain of the judge. But he stated that, in order to render the verdict demanded by the bench in the Penn and Mead trials, the jurors would have had to accept the bench's version of the facts, directly contradicting the principle that the jury, rather than the judge, is empowered by the common law to find the facts. Chief Justice Vaughan elaborated by, among other things, pointing out that even if all the proof is presented in open court, the judge and jury might honestly differ in the result from the evidence. ${ }^{104}$ Thus even though the jury might, in reality, be flouting the law or choosing to ignore the facts, its verdict could be justified on the theory that it simply came to a different conclusion on the facts than the trial judge. Consequently, the jurors' fines were ordered remitted and an important principle had been affirmed - jurors should never be punished or threatened with punishment by the bench for returning a verdict against the trial judge's perception of the weight of the evidence. case, and a complete critique of the full reasoning of the court in Bushel's Cose. sec Giretn. lerdict. supra note 5 at $236-49$.

(16) Each chapter of Green, ibid, addresses the topic of jury nullitication in England from the thirteenth tI, the eighteenth centuries as well as its impact on the English criminal justice system and substantive criminal law. 
Even before Bushel 's Case, judges who disagreed with jury verdicts could have opted to take less confrontational steps than ordering a fine for disobedient jurors. If a judge disagreed with a guilty verdict by a jury, the judge could simply recommend a pardon for the offender, and such a recommendation was invariably followed.

A judge who sensed that he and the jury hearing a case were not of the same view had two options. He could abort the trial before the case went to verdict and have it tried again later to another jury, or he could direct a jury to return a special verdict. Under this latter procedure, judges asked juries to state the facts of the case, but the court reserved to itself the determination of whether those facts gave rise to criminal liability. The power to order special verdicts was dealt a fatal blow in 1792. Prior to 1792, judges were ordering special verdicts on the question of whether or not accused had published certain items. Once the matter of publication was decided, the bench determined whether the publications were seditious. In 1792, Parliament gave the jury the power to render a general verdict of guilty or not guilty in relation to the offence of seditious libel. ${ }^{105}$ In other words, juries could not be forced to render special verdicts in relation to this offence. Soon the judiciary was to lose the ability to force juries to render special verdicts in relation to common felonies as well.

One particularly noteworthy change that occurred during the era of the altercation trial was that judges became less reluctant to pierce the veil of the jury verdict when they thought the verdict was against the weight of the evidence. When a jury returned a verdict that the judge thought was contrary to his assessment of the evidence, the judge could refuse to accept the initial verdict, probe its basis with the jurors, give them further instruction and require them to redeliberate. ${ }^{106}$ Yet if the jury refused to revise its verdict after redeliberation, the court was bound to accept the verdict.

With the emergence of the adversarial criminal trial, judges were forced by lawyers to begin, once again, to respect the inscrutability of general jury verdicts:

The suggestion is that counsel's assumption of responsibility for adducing fact cost the judges some of the authority upon which the older techniques of jury control had depended. Judge and jury had worked together to discern from the spectacle of the altercation trial whether the accused was culpable. As counsel assumed responsibility for the production and presentation of the evidence, the jurors became less dependent on the judge for his... [a]ssistance ... in forming their view of the case. Counsel now spoke directly to the jurors, advancing opposing interpretations and suggesting outcomes. This development undercut the judge's former authority with respect to both the facts and the law, an authority that had come from his having helped elicit the facts, and from his having been the only source of professional guidance for interpreting the facts and applying the law. As the adversary system took hold, counsel for the prosecution and defence came to supply the jurors with multiple and conflicting views on the facts and the law. Across time the responsibility for interpreting the evidence passed from court to counsel. By broadening the jurors' sources, the adversary system inevitably undermined the authority of the judge and increased the potential for the jury to form a view statule. the controversy surrounding the ordering of special verdicts for the offence of seditious libel, and the link between this controversy and the older debate over whether the jury was a finder of law as well as fact, see Green, Verdict, supra note 5 at 153-99. 318-55. 
of the case different from the judge's. In this way, lawyerization of the trial contributed to the break-up of the ancient working relationship of judge and jury. ${ }^{107}$

Lawyers wanted to increase the likelihood that counsel's version of the facts, the application of the law to the facts, and perhaps even the law would be accepted by the jury. Judicial probing of jury verdicts would, at least in some instances, impede the achievement of this objective. Consequently, lawyers began to successfully insist that judges stop inquiring into the bases of criminal trial jury verdicts. As the judiciary lost their ability to identify and correct jury error, the judges devised a new system, based on the law of evidence and the law of jury instructions. This system is the system we have today, a system that is designed not to root out and ameliorate jury mistakes but one that is designed to prevent jury error.

\section{ConcLusion}

The preceding historical account reveals the origins of the criminal trial jury in England. When clerical participation in the ordeal was prohibited, a substitute for the ordeal had to be found.

The criminal trial jury was chosen as that substitute for two reasons. First, there was already an existing tradition of criminal juries delivering medial verdicts that sometimes resulted in de facto punishment. As a result, it was a relatively short step to grant juries the power of final verdict with its attendant official sanction. Second, there had not been a tradition of English judges delivering verdicts in serious criminal matters. Instead, prior to the advent of the criminal trial jury, English judges at most administered, or arranged for the administration of, the pre-criminal trial jury forms of proof. Consequently, the use of the criminal trial jury facilitated the maintenance of the status quo - English judges would continue their familiar role as administrators of the justice system, and they would continue to avoid becoming true adjudicators of criminal allegations.

In the beginning, the criminal trial jury was extremely active. Jurors went out and investigated allegations themselves and, in large part, the jury simply reported its findings to the trial judge. It has been argued that the jury's virtually exclusive monopoly as a source of evidence during medieval times often led the jury to embellish or outright misreport the facts pertaining to criminal matters so as to provide accused with a means of avoiding the unduly harsh punishments that would have followed the strict application of the law, as construed by the bench, to the true facts. ${ }^{108}$ Because judges' primary source of the facts was the jury, the judiciary had little reason to question the findings or verdicts of the jurors.

Ibid. at 331 [footnotes omitted].

See, for example, Green, Verdict, supra note 5 at 28, 30, 37-63, 97-102. It must be semembered that until the 1830 s most felonics were punishable by death. However, many individuals avoided the gallows prior to the early eighteenth century by successfully claiming benefit of clergy. Originally, this privilege that saved an individual from capital punishment even though found guily of a capital offence only extended to ordained clerics. However, eventually benefil of clergy was exiended to all those who could read. The types of oflences to which one coutd claim bencfit of clergy varied over time and the privilege finally was abolished in England in 1827. For more information on benefit of clergy, see Baker, supra note 16 at 513-15; Leona C. Gabel, Benefil of Clergy in Eingland in the Laser Middle Ages (New York: Octagon Books, 1969) (originally published 1928-1929): and George W. Dalzell, Benefit of Clergy in America \& Related Matters (Winston-Salem: J.F. Blair. 1955). 
Juries became more passive when they relinquished their investigatory roles and began to rely upon the evidence presented to them in court. When witnesses began to dominate trials, judges were privy to the same evidential sources that juries relied upon. As a result, on occasion judges and juries came into conflict over the propriety of the jury's verdict. To assist them in resolving these conflicts in their favor, judges assumed a number of powers in relation to the jury, including the power to probe jury verdicts and order juries to redeliberate. As a result, it became more difficult for jurors to engage in jury nullification. Nevertheless, the jury was still more active than it is today. Among other things, it often called for further witnesses to be summoned and directly questioned witnesses.

However, control over the evidence and the questioning of witnesses was eventually wrestled from the other participants in the trial, both judge and jury, by the lawyers. The jurors became bystanders to a trial process that was controlled largely by prosecuting and defending counsel. In order to curtail the influence of the judiciary, the lawyers persuaded the bench to accept as inscrutable the general verdicts of criminal trial juries. With this development, the prospect of jury nullification in appropriate circumstances was revived because the jury could use the general verdict to conceal its rejection of the law as expounded by the bench. The inscrutability of the general verdict made it difficult for the trial judges to detect and correct problematic juror reasoning as trial judges did not have an authoritative basis for knowing what motivated juries' decisions. Because judges lost the ability to detect jury error, they attempted to prevent it by giving more detailed jury instructions and by developing complex exclusionary rules of evidence. Indeed, this legacy of often confusing and counterintuitive jury instructions and rules of evidence is one that remains with us to this very day.

Yet the modern relevance of the history of the English criminal trial jury may go beyond the explanation of present day legal phenomena. This history provides fodder for those who argue that the criminal trial jury is not an inflexible anachronism that needs to be abolished, but an institution that is worth retaining, one that has proven its adaptability numerous times in the past and is capable of doing so again in the future. To those individuals who wish to retain trial by jury but who recognize the system can be improved, the historical record may provide a source for reform proposals. Perhaps what was old will become new again. 